\title{
The Role of Leukotrienes as Potential Therapeutic Targets in Allergic Disorders
}

\author{
Airi Jo-Watanabe, Toshiaki Okuno and Takehiko Yokomizo * $\mathbb{D}$ \\ Department of Biochemistry, Juntendo University School of Medicine, Tokyo 113-8421, Japan \\ * Correspondence: yokomizo-tky@umin.ac.jp; Tel.: +81-3-5802-1030
}

Received: 9 June 2019; Accepted: 19 July 2019; Published: 22 July 2019

\begin{abstract}
Leukotrienes (LTs) are lipid mediators that play pivotal roles in acute and chronic inflammation and allergic diseases. They exert their biological effects by binding to specific G-protein-coupled receptors. Each LT receptor subtype exhibits unique functions and expression patterns. LTs play roles in various allergic diseases, including asthma (neutrophilic asthma and aspirin-sensitive asthma), allergic rhinitis, atopic dermatitis, allergic conjunctivitis, and anaphylaxis. This review summarizes the biology of LTs and their receptors, recent developments in the area of anti-LT strategies (in settings such as ongoing clinical studies), and prospects for future therapeutic applications.
\end{abstract}

Keywords: leukotriene; $\mathrm{LTB}_{4}$; BLT1; cysteinyl leukotriene; allergic disease; asthma

\section{Introduction}

Lipid mediators, which denote bioactive mediators derived from lipids, play roles in immune regulation, self-defense, and the maintenance of homeostasis in living systems. They include prostaglandins (PGs) and leukotrienes (LTs), lysophospholipids (including sphingosine 1-phosphate), and endocannabinoids [1]. LTs, which are derived from arachidonic acid (5Z,8Z,11Z,14Z-eicosatetraenoic acid; AA) through two steps catalyzed by 5-lipoxygenase (5-LO), are inflammatory mediators that function in normal host defense and play roles in inflammatory diseases [2].

They exert their biological effects by binding to G-protein-coupled receptors (GPCRs). Different LT receptor subtypes exhibit unique functions and expression patterns. LT receptors BLT1 and BLT2 are activated by leukotriene $\mathrm{B}_{4}\left(\mathrm{LTB}_{4}\right)$, whereas CysLT1 and CysLT2 receptors are activated by cysteinyl LTs (CysLTs) [3]. LTs are involved in various inflammatory diseases, including asthma, allergic rhinitis (AR), atopic dermatitis (AD), allergic conjunctivitis, rheumatoid arthritis, anaphylaxis, chronic obstructive pulmonary disease (COPD), obliterative bronchiolitis after lung transplantation, and interstitial lung diseases [4]. This review summarizes the biology of LTs and their receptors, along with recent findings related to the pathophysiological roles of LTs and their signaling pathways in allergic diseases. We also discuss both current and future therapeutic prospects.

\section{Biosynthesis and Metabolism of LTs}

Lipids are the major components of cell membranes. Phospholipids containing AA, a polyunsaturated fatty acid comprising 20 carbon atoms, are an important component of cell membranes. In response to various stimuli, $\mathrm{AA}$ is released from phospholipids by phospholipase $\mathrm{A}_{2}$ (PLA $\mathrm{P}_{2}$, particularly cytosolic $\mathrm{PLA}_{2} \alpha$ [1]. AA can be metabolized by various pathways, but two pathways, the 5-LO pathway and the cyclooxygenase (COX) pathway, are important in producing bioactive lipid mediators. The 5-LO pathway generates LTs from AA, while the COX pathway generates PGs and thromboxane $[5,6]$. 
LTs are classified into two groups: the chemoattractant $\mathrm{LTB}_{4}$, which only carries hydroxyl moieties, and CysLTs $\left(\mathrm{LTC}_{4}, \mathrm{LTD}_{4}\right.$, and $\mathrm{LTE}_{4}$ ), which also carry amino acid moieties [7]. AA is first oxidized by 5-LO at the $\mathrm{C}-5$ position to yield 5-hydroperoxyeicosatetraenoic acid (5-HpETE). It is then converted to an unstable intermediate, leukotriene $\mathrm{A}_{4}\left(\mathrm{LTA}_{4}\right) ; \mathrm{LTA}_{4}$ is either converted to $\mathrm{LTB}_{4}$ by $\mathrm{LTA}_{4}$ hydrolase $\left(\mathrm{LTA}_{4} \mathrm{H}\right)$ or conjugated to reduced glutathione by leukotriene $\mathrm{C}_{4}$ synthase $\left(\mathrm{LTC}_{4} \mathrm{~S}\right)$, yielding $\mathrm{LTC}_{4}$ [2]. $\mathrm{LTC}_{4}$ is then exported from the cell through transporters, such as multidrug-resistant protein 1 , which recognize glutathione-containing molecules, and then converted to $\mathrm{LTD}_{4}$ and $\mathrm{LTE}_{4}$ by extracellular peptidases [7]. Signaling via BLT1 triggers chemotaxis, inflammation, and immune responses, whereas that through CysLTs results in bronchoconstriction, eosinophil recruitment, exacerbated vascular permeability, and chronic inflammation (Figure 1).

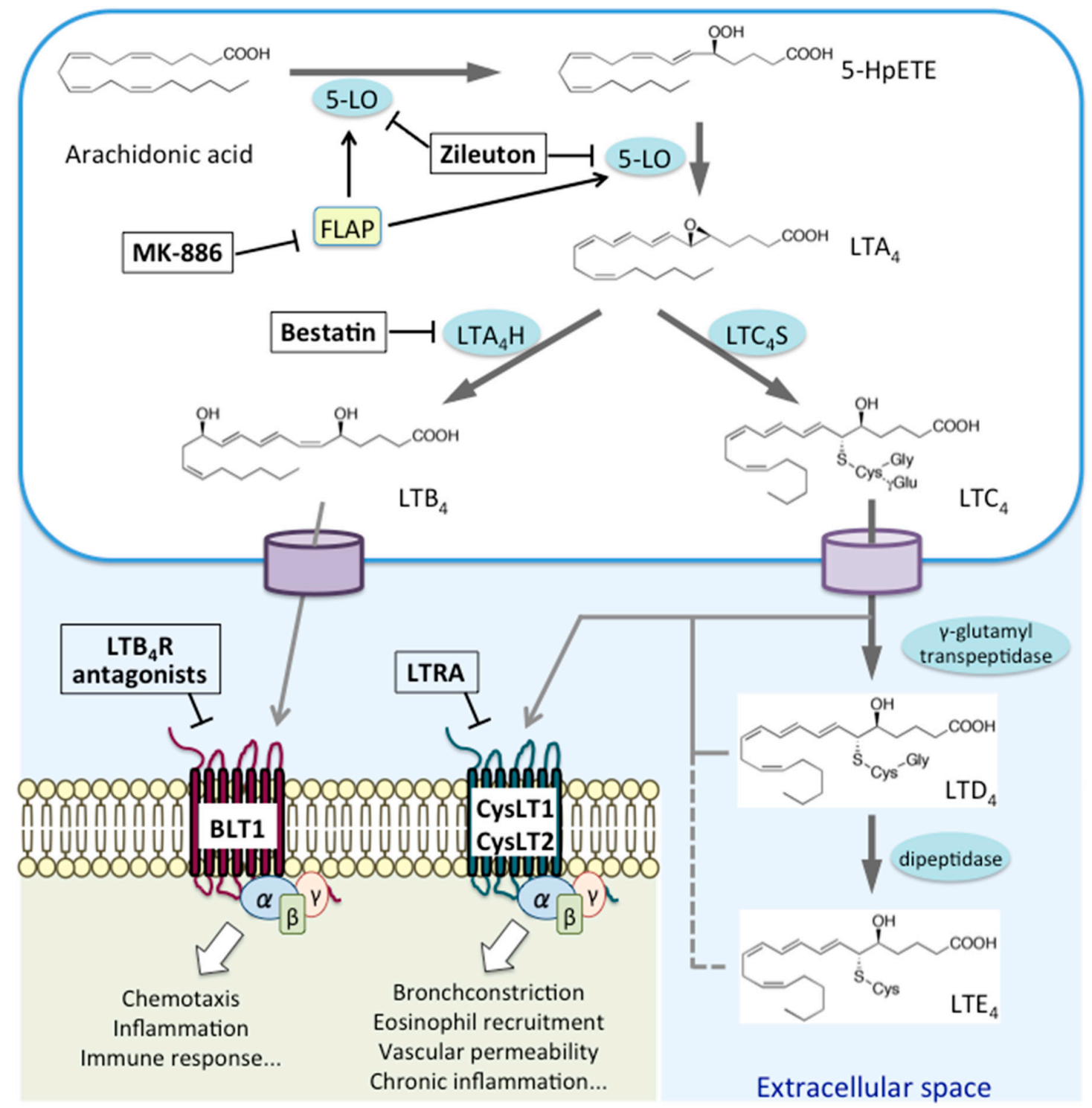

Figure 1. Biosynthetic pathways and receptors for leukotrienes.

\section{Expression of LT Receptors and Their Associated Signaling Pathways}

Like other lipid mediators, PGs and LTs function as signaling molecules through specific GPCRs. BLT1 and BLT2 are activated by $\mathrm{LTB}_{4}$, whereas CysLT1 and CysLT2 are activated by CysLTs. There are many reports and controversies about the novel functions of LT-related signaling. Indeed, studies demonstrated BLT1 and BLT2 signaling in cancer. Whereas BLT1 was shown to accelerate tumor 
progression by enhancing inflammation [8], recent studies demonstrated that BLT1-mediated CD8 ${ }^{+}$ $T$ cell recruitment was essential for initiating antitumor immunity $[9,10]$. BLT2, on the other hand, accelerates chemotherapy resistance and tumor promotion [11]. The dual pro- and anti-inflammatory activities of the BLT2 receptor have added complexity, since BLT2-deficient mice exhibited reduced severity in arthritis models [12], whereas the deletion of BLT2 caused more severe colitis induced by dextran sulfate possibly due to the loss of BLT2-dependent intestinal barrier function [13]. Crosstalk between the CysLT1/2 and P2Y receptor systems has also been described [14,15].

Similar controversies surround novel receptors for CysLTs. For example, GPR99 was identified as a receptor for $\mathrm{LTE}_{4}$ [16]. The orphan GPR17, phylogenetically located at an intermediate position between the P2Y and CysLT receptors, was originally thought to be activated by CysLTs, nucleotides, and sugar nucleotides (UDP, UDP-glucose, and UDP-galactose) [17]; however, the action of GPR17 as a dual receptor for both CysLTs and nucleotides is yet to be proven [18]. Additionally, lipoxygenase metabolites derived from essential $\omega-3$ polyunsaturated acids (the resolvins) activate the receptors GPR32 and ChemR23 [3]. The orphan receptor GPR32 was identified as a receptor for RvD1 [19], RvD5 [20], and RvD3 [21], and ChemR23 was initially described as one of three GPCRs that are activated by the chemotactic protein chemerin [22,23] (it is classified therefore as a proinflammatory receptor). However, subsequent studies using ChemR23 knockout mice as the basis for different disease models revealed its anti-inflammatory role. Indeed, ChemR23 was identified as a high-affinity RvE1 receptor through screening of the ability of RvE1 to inhibit TNF $\alpha$-induced NF- $\mathrm{kB}$ activation in HEK293 cells transfected with candidate GPCRs [24].

\section{1. $\mathrm{LTB}_{4}$ Receptors: BLT1 and BLT2}

$\mathrm{LTB}_{4}$, which binds to the BLT1 receptor, is one of the most potent chemoattractants for many immune cells $[25,26]$. Studies report expression of BLT1 by nonmyeloid cells such as vascular smooth muscle cells, endothelial cells, skeletal muscle satellite cells, and neural stem cells, albeit at low levels [27-29]. Recent studies show that the $\mathrm{LTB}_{4}$-BLT1 axis plays a role in a variety of diseases other than allergic diseases; these include arthritis, COPD, cardiovascular diseases, age-related macular degeneration (AMD), cancer, and metabolic disorders (which are mentioned briefly in Section 6 below).

The BLT2 gene lies adjacent to that of BLT1 in both humans and mice. BLT2 was first identified as a low-affinity receptor for $\mathrm{LTB}_{4}$ [30]; the dissociation constant $(K \mathrm{~d})$ (which is used to describe the affinity between a ligand and its cognate receptor) for binding of BLT2 to $\mathrm{LTB}_{4}$ is 20 -fold higher than that of BLT1, and it induces calcium signaling at a 30 -fold higher median effective concentration $\left(\mathrm{EC}_{50}\right)$ (the concentration of ligand that induces a response halfway between the baseline and maximum) [31] than BLT1. Soon after, 12(S)-hydroxyheptadeca-5Z,8E,10E-trienoic acid (12-HHT), a downstream metabolite of COX enzymes, was identified as an endogenous ligand of BLT2 [32]. BLT2 is expressed at high levels by epithelial cells in various tissues, including intestine, skin, and cornea; the 12-HHT-BLT2 axis accelerates skin [33] and corneal [34] wound healing, and plays a protective role in acute lung injury $[25,35,36]$.

\subsection{CysLTs Receptors: CysLT1 and CysLT2}

CysLTs, namely, $\mathrm{LTC}_{4}, \mathrm{LTD}_{4}$, and $\mathrm{LTE}_{4}$, are proinflammatory lipid mediators with bronchoconstricting ability. They are involved in the pathogenesis of allergic diseases such as asthma and AR. CysLTs are produced mainly by eosinophils, mast cells (MCs), and macrophages in response to a variety of stimuli [37]. CysLT1 is sensitive to classical CysLT antagonists such as montelukast, zafirlukast, pranlukast, pobilukast, and MK571. By contrast, CysLT2 is insensitive to these antagonists; indeed, there were no CysLT2-selective antagonists until recently [3,38]. Therefore, the role of the latter in allergic diseases remains unclear. Their affinity for CysLT1 is ranked as follows: $\mathrm{LTD}_{4}>\mathrm{LTC}_{4}>\mathrm{LTE}_{4}$ [39]. Meanwhile CysLT2 binds $\mathrm{LTC}_{4}$ and $\mathrm{LTD}_{4}$ with an affinity one log less than that of CysLT1 (binding rank order: $\mathrm{LTD}_{4}=\mathrm{LTC}_{4}>\mathrm{LTE}_{4}$ ) [40]. An ex vivo study of isolated human 
small bronchus revealed that the potency (as determined by their effect on bronchoconstriction) is $\mathrm{LTC}_{4} \geq \mathrm{LTD}_{4}>\mathrm{LTE}_{4}[41]$.

CysLT1 is expressed by bronchial smooth muscle [39,42], whereas CysLT2 is expressed at high levels by endothelial cells within some vascular beds (including coronary vessels), and is implicated in a variety of cardiovascular functions such as increased vascular permeability and reduced systemic blood pressure [43].

\subsection{GPR99}

As stated above, both CysLT1 and CysLT2 have lower affinity to LTE 4 , the most stable CysLT. LTE 4 is the most abundant CysLT present at sites of inflammation [44], where it induces airflow obstruction and eosinophil infiltration in patients with asthma. These facts suggest that another signaling pathway specific for $\mathrm{LTE}_{4}$ is involved in airway inflammation. GPR99, previously described as an oxoglutarate receptor (OXGR1), recently emerged as a potential novel receptor for $\mathrm{LTE}_{4}$ that mediates cutaneous vascular permeability in mice deficient in the terminal enzyme for CysLT biosynthesis, $\mathrm{LTC}_{4}$ synthase [16,45]. GPR99 is expressed on lung and nasal epithelial cells as well as on vascular smooth muscle cells in the nasal mucosa [46], where it modulates mucin release and goblet cell numbers [47]. Further studies are required to confirm whether GPR99 functions as a receptor for LTE 4 .

\section{LTs and Allergic Diseases}

\subsection{Asthma}

Asthma is a common and potentially serious chronic disease that imposes a substantial burden on patients. It causes respiratory symptoms, limits activity, and is prone to flare-ups (attacks) that sometimes require urgent healthcare and may be fatal. Asthma symptoms include wheezing, shortness of breath, chest tightness, and cough; the occurrence, frequency, and intensity of these symptoms vary over time. Difficulty in expelling air from the lungs is due to bronchoconstriction, airway wall thickening, and increased mucus production.

Some drugs, such as beta-blockers, aspirin, and NSAIDs, as well as viral infections, allergens, tobacco smoke, exercise, and stress, can trigger/induce asthma symptoms. The gold standard treatment is inhaled corticosteroid (ICS)-containing medication, but treatment should be customized to the individual patient (https://ginasthma.org/pocket-guide-for-asthma-management-and-prevention/).

\subsubsection{Pathology}

Asthma is a complex and chronic disorder of the airways that is characterized by airflow obstruction, airway inflammation, and airway hyper-responsiveness (AHR). Airway inflammation plays an essential role in the pathogenesis of asthma and is characterized by infiltration of the airways by inflammatory cells such as neutrophils, eosinophils, and lymphocytes [48]. LT-mediated pathways are implicated in the pathophysiology of asthma [49]. The presence and elevated levels of numerous metabolites in the blood, sputum, and bronchoalveolar lavage (BAL) fluid from asthmatics or experimental animals supports this notion [49]. Asthma therapies that target CysLT1 are successful [50], but clinically are effective only in certain situations. Although one 5-LO inhibitor, zileuton, is approved for treatment of asthma [51], interference with other molecules in LT biosynthesis and signaling pathway means that it is not fully effective. Roles for BLT2 in asthma have been reported, although to a lesser extent than that of BLT1 [49,52-54].

\subsubsection{The $\mathrm{LTB}_{4}-\mathrm{BLT1}$ Pathway in Asthma}

The importance of the $\mathrm{LTB}_{4}-\mathrm{BLT1}$ pathway in the pathogenesis of asthma is supported by extensive experimental data and findings (albeit limited) from clinical samples. For example, both levels of 5- $\mathrm{LO}$ and $\mathrm{LTA}_{4} \mathrm{H}$ in the airways and the number of circulating neutrophils are higher in patients with asthma than in those without $[55,56]$. Increased levels of $\mathrm{LTB}_{4}$ are detected in the blood, BAL 
fluid [57], and exhaled breath condensate (EBC) [58,59] from children and adolescents with asthma. In contrast to CysLTs, which are potent mediators of bronchoconstriction [48], $\mathrm{LTB}_{4}$ is a proinflammatory mediator that has a major effect on recruitment, activation, and survival of myeloid leukocytes [60]. Accumulation of neutrophils and eosinophils is considered to be a pathological parameter in asthma patients [61].

Based on the type of inflammatory cell in sputum, asthma is divided into four phenotypes: eosinophilic asthma, neutrophilic asthma, mixed granulocytic asthma, and paucigranulocytic asthma. Neutrophilic asthma is difficult to treat due to poor steroid responsiveness [62], being the predominant pattern in acute exacerbation of asthma in adults [63]. It occurs frequently in those with steroid-insensitive asthma [64-66], severe asthma [67], and occupational asthma [68].

Massive numbers of neutrophils are present in the airways of asthmatics suffering from clinical exacerbations or asthma-related sudden death $[69,70]$. Therefore, targeting and modulating the $\mathrm{LTB}_{4}-\mathrm{BLT1}$ pathway will offer innovative therapeutic opportunities, especially for patients with asthma that remains uncontrolled despite intensive corticosteroid treatment [49].

In addition to its important role as a neutrophil chemoattractant, another important role of the $\mathrm{LTB}_{4}-\mathrm{BLT1}$ pathway (despite observations made more than two decades ago) was shown only recently; the pathway plays an important role in recruiting and activating T cells [71] and dendritic cells, the major antigen-presenting cell in the lung [49]. Allergen-specific memory T cells and IgE-specific antibodies are required for these responses. It is now recognized that many $\mathrm{T}$ cell subtypes, such as $\mathrm{CD} 4^{+}$and $\mathrm{CD}^{+} \mathrm{T}$ cells, contribute to the pathophysiology and development of allergic airway responses [72]. BLT1-deficient mice are resistant to OVA-induced allergic AHR and show reduced accumulation of neutrophils, eosinophils [73], lymphocytes [74], and dendritic cells in the lungs [75]. In agreement with a mouse model of allergic pulmonary inflammation [76], large numbers of BLT1-expressing effector memory $\mathrm{CD}^{+} \mathrm{T}$ cells are present in BAL fluid from asthmatic patients [77].

Although accumulating evidence demonstrates the importance of $\mathrm{LTB}_{4}$ in asthma, previous studies failed to show the effectiveness of targeting the $\mathrm{LTB}_{4}-\mathrm{BLT} 1$ pathway as a treatment for asthma. A clinical trial of the BLT receptor antagonist LY293111 in 12 asthmatic patients showed that it led to a significant reduction in the number of neutrophils in BAL fluid, but failed to improve respiratory function or airway reactivity after allergen challenge [78]. Studies in a guinea pig asthma model showed that LY293111 had no effect on eosinophil and macrophage infiltration into the BAL fluid [79]. However, a study examining the role of another BLT1 antagonist, CP-105,696, in monkeys showed that the compound inhibited $\mathrm{LTB}_{4}$-mediated neutrophil chemotaxis and upregulation of CD11b $\mathrm{b}^{+}$cells in BAL, leading to amelioration of AHR [80].

A recent in vivo study in BLT2-deficient mice indicates that BLT2 protects against allergic airway inflammation and that reduced expression of BLT2 by CD4 ${ }^{+} \mathrm{T}$ cells might contribute to the pathophysiology of asthma [52]. Also, an increasing number of studies have demonstrated that BLT2 has a protective role in allergic airway inflammation $[49,53,54]$.

\subsubsection{The CysLT Pathway in Asthma}

CysLTs are thought to be essential for the pathogenesis of acute and chronic asthma because they are the most potent bronchoconstrictors in humans [48,81]; indeed, they are much more potent than histamine [82]. CysLTs are detected in blood, BAL fluid, and urine samples from asthmatic patients after bronchospasm. The contribution of the CysLT1 signaling pathway in the clinical manifestations of asthma is supported by the finding that, in addition to the 5-LO inhibitor zileuton [51], CysLT receptor antagonists or leukotriene receptor antagonists (LTRAs) montelukast, zafirlukast, and pranlukast are effective treatments $[37,83]$. Moreover, epigenetic changes in the genes encoding CysLT1 and $\mathrm{LTC}_{4} \mathrm{~S}$ confer susceptibility to asthma. Particulate matter with an aerodynamic diameter of $<2.5 \mu \mathrm{m}$ (PM2.5) exacerbates asthma symptoms [84], and a recent genome-wide study demonstrated that the effects of acute PM2.5 exposure are associated with changes in CysLT1 expression and methylation of CpG sites on the CysLT1 and $\mathrm{LTC}_{4} \mathrm{~S}$ genes [85]. 
In recent years, accumulating evidence has shown that CysLTs, among other mediators (cytokines, chemokines, growth factors, alarmins, and lipid mediators), play essential roles in regulating eosinophil recruitment [37]. Indeed, CysLTs display eosinophilotactic activity in vitro via CysLT1 [86,87]. In vivo, involvement of CysLTs in eosinophil influx was first demonstrated in guinea pigs in the 1990s [88], and then in humans [89]. Recently, a study described the roles of $\mathrm{LTC}_{4}$ in mediating eosinophil trafficking from the lungs to the paratracheal lymph nodes in experimental allergic asthma [90]. Activation of CysLT1 is also important for eosinophilic inflammation because it upregulates expression of endothelial adhesion molecules [86,91], induces eosinophil chemotaxis, and reduces eosinophil apoptosis [92]. Eosinophils are thought to be the main cellular source of CysLTs; these cells express CysLT1 on the membrane, suggesting that this molecule has autocrine activity [93].

Studies show that respiratory parameters related to lung microvascular leakage and lung edema in antigen-challenged Brown Norway rats are improved partially by inhibitors of AA metabolism; these inhibitors include indomethacin (a COX inhibitor) and montelukast. These data indicate that one of the mechanisms by which CysLTs affect the pathophysiology of asthma is based on CysLT-dependent exacerbation of vascular leakage and mucosal edema [94].

CysLTs also play a role in airway remodeling by promoting proliferation of airway smooth muscle cells [95] and epithelial cells [96], and by increasing collagen deposition [97], which is an important feature of chronic asthma [98].

It is not clear how CysLT2 signaling contributes to the pathophysiology and manifestations of asthma since no specific antagonists were available until recently [37]. Currently, an increasing number of reports demonstrate involvement of CysLT2 [91,99]. Future studies will likely support a role for CysLT2 in the pathophysiology of asthma.

\subsection{Exercise-Induced Asthma (EIA)}

EIA, a type of asthma common in children, causes airway narrowing during exercise; symptoms include cough and shortness of breath [100]. Studies report involvement of CysLTs in EIA [101]. In addition, leukotriene receptor antagonists (LTRAs) and ICS are useful for long-term management of asthma patients complicated by EIA and AR [102].

Several observational studies suggest involvement of LTs in EIA; one study reports that exercise-induced stress increases transcription of genes encoding 5-LO and 5-LO-activating protein (FLAP), thereby increasing production of $\mathrm{LTB}_{4}$ and $\mathrm{LTC}_{4}$ in plasma after exercise [103], whereas another reports that levels of CysLTs in EBC from EIA patients are higher than those in controls, and that they increase after exercise challenge [104]. Despite the clinical effectiveness of LTRAs on EIA, few experimental studies have examined the role of LTs in the pathogenesis of EIA. One study that analyzed $\mathrm{LTB}_{4}$ production by peripheral blood mononuclear cells (PBMCs) isolated before and after EIA demonstrated a several-fold increase in production of $\mathrm{LTB}_{4}$ by PBMCs isolated after EIA when compared with those isolated before exercise [105].

\subsection{Aspirin-Sensitive Asthma (ASA)}

ASA is a particular phenotype of severe late-onset asthma. The correlation between aspirin sensitivity, asthma, and nasal polyposis was recognized in the early 20th century. Today, chronic rhinosinusitis with nasal polyposis, bronchial asthma, and reactions to aspirin or COX-1 inhibitors (eponymously named Samter's Triad) is a manifestation of aspirin-exacerbated respiratory disease (AERD) [106]. AERD affects approximately $0.3-0.9 \%$ of the general population in the USA, and approximately $7 \%$ of those with asthma [107].

The pathophysiology of AERD is characterized by a non-IgE hypersensitivity reaction to ASA/COX-1 inhibitors; the reaction is commonly comorbid and not due to underlying allergic diseases [6]. AERD is thought to be caused by abnormalities in AA biosynthesis [108,109]. Importantly, specific COX-2 inhibitors do not cause respiratory reactions in patients with AERD [110]. 
The mechanism underlying AERD is likely to relate to constitutive overproduction of CysLTs, with a concomitant decrease in downstream products of the COX-1 pathway, the latter of which have an inherent inhibitory effect on CysLTs $[109,111]$. This results in a proinflammatory environment. Indeed, CysLTs are implicated in development of rhinitis and AERD through three mechanisms: (1) increased vasodilation and permeability of the nasal vasculature leading to mucosal edema and nasal congestion; (2) increased inflammation at the level of the sinonasal epithelium resulting in more mucus production and rhinorrhea; and (3) augmented inflammation through recruitment of inflammatory cells [112]. The elevated levels of CysLTs found in the urine, sputum, exhaled breath, and peripheral blood of AERD patients support this theory $[108,112]$.

Investigations into the precise mechanisms underlying the constitutive overproduction of CysLTs are ongoing. One study examined the possible mechanism underlying increased levels of CysLTs in AERD. The report showed that the cytokine milieu in AERD did contain higher levels of IFN- $\gamma$ than that in those with asthmatic or eosinophilic sinusitis; increased IFN- $\gamma$ stimulated differentiation of eosinophils, leading to marked upregulation of the number of infiltrating eosinophils; in turn, those IFN- $\gamma$-differentiated eosinophils increased the levels of LTC $_{4}$ [113]. Moreover, eosinophils secrete numerous cytokines and chemokines such as interleukin (IL)-4. Both IL-4 and IFN- $\gamma$ upregulate expression of CysLT1 by multiple cell lines, including eosinophils and MCs [114]. According to several studies that examined the role of IL-33 in AERD, IL-33 may act as a bridge between CysLT overexpression and MC activation, which is one of the characteristics of AERD. CysLTs induce IL-33 expression, and IL-33 stimulates MCs to generate $\mathrm{PGD}_{2}$, thromboxane $\mathrm{A}_{2}$, and CysLTs [115]. In addition, platelet-adherent leukocytes are effectors of AERD and lead to increased levels of CysLTs [116]. Finally, lipoxins are anti-inflammatory mediators that typically downregulate expression of proinflammatory cytokines by competing for the CysLT1 receptor. Interestingly, although CysLT1 is upregulated in patients with AERD, there is a simultaneous downregulation of lipoxins, leading to inadequate competition with CysLTs for the receptor; this contributes to CysLT-driven pathophysiology [116-118].

Finally, another study demonstrated possible involvement of CysLT2 in ASA; CysLT2 signaling, IL-33-dependent ILC2 (innate lymphoid cells) expansion, and IL-33-driven MC activation are necessary for induction of type 2 immunopathology and aspirin sensitivity, indicating that CysLT2 might be a potential target for the treatment of ASA [119].

\subsection{Allergic Rhinitis (AR)}

AR, which is characterized clinically by sneezing, rhinorrhea, nasal itching, and congestion, is an allergen-driven mucosal inflammatory disease that is modulated by IgE. Epidemiological studies indicate that the prevalence of AR continues to increase; indeed, it is a worldwide health problem that places a significant healthcare burden on individuals and society [120]. AR affects $20-30 \%$ of adults both in the United States and Europe, and the prevalence is perhaps somewhat higher in children [121].

CysLTs increase vascular permeability, leading to nasal congestion, increased mucus production and secretion, rhinorrhea, and recruitment of inflammatory cells into tissues. Recent evidence suggests involvement of CysLTs in the pathophysiology of AR: CysLTs are released from inflammatory cells that participate in AR [122], receptors for CysLTs are located in nasal tissue [123], and CysLT levels are increased in nasal lavage fluid from patients with AR [124]. Increasing numbers of studies demonstrate that patients with AR respond favorably to treatment with CysLT receptor antagonists. By binding competitively to CysLT1, LTRAs such as montelukast, zafirlukast, and pranlukast block the effects of CysLTs and improve the symptoms of chronic respiratory diseases, particularly bronchial asthma and AR [120]. A recent meta-analysis suggests that H1-antihistamines (SAH) and LTRA have similar effects and safety profiles when used to treat seasonal AR; however, SAH is more appropriate for daytime nasal symptoms (congestion, rhinorrhea, pruritus, and sneezing) while LTRA is better suited for night-time symptoms (difficulty going to sleep, night-time awakenings, and nasal congestion on waking) [125]. Accumulating evidence shows the effectiveness of combination therapy with LTRAs and AH. One meta-analysis shows that, compared with SAH alone, LTRAs + SAH show increased 
therapeutic efficacy against daytime and composite nasal symptoms, although they do not affect night-time nasal symptoms and eye symptoms. The study also demonstrates the possibility that patients with perennial AR benefit more from combination therapy [126]. Another study also shows that combination therapy with LTRA + SAH provides greater beneficial effects against composite nasal symptoms, rhinorrhea, sneezing, and rhinoconjunctivitis symptoms in patients with AR and patients with perennial AR [127].

The role of $\mathrm{LTB}_{4}$ in $\mathrm{AR}$ is unclear, although several studies report that patients with AR show increased levels of $\mathrm{LTB}_{4}$ in the nasal cavity and EBC [128], suggesting involvement of $\mathrm{LTB}_{4}$ in the pathogenesis of AR.

Overall, antileukotrienes, in combination with SAH, are effective against AR and result in significant improvements in daytime nasal symptoms and quality of life.

\subsection{Atopic Dermatitis (AD)}

$\mathrm{AD}$ is the most common inflammatory dermatological disorder. It is either chronic or chronically relapsing, and characterized by intense pruritus and dry skin. The incidence of AD has increased over the last few decades; indeed, $10-25 \%$ of children and $2-8 \%$ of adults in affluent nations are affected. Of all patients affected, up to one quarter have moderate-to-severe disease [129]. Approximately one-third of patients carry the disease into adulthood; thus the disease becomes life-long. Glucocorticoids have long been the gold standard treatment, but use is limited by their adverse side effects [130].

The underlying etiopathogenesis of $\mathrm{AD}$ is multifaceted; however, key elements are an impaired skin barrier, dysregulated immune responses, immunologic abnormalities, and subsequent release of inflammatory mediators [131]. The role of LTs and PGs in development of AD was established prototypically in studies of asthma pathogenesis. As in asthma, high concentrations of eicosanoids are present in skin affected by AD. PGD 2 is the main PG produced by MCs [132]; $\mathrm{PGE}_{2}$ and $\mathrm{LTB}_{4}$ are also present at high concentrations [133]. Additionally, a recent study that investigated serum metabolic abnormalities in AD children found that the differential metabolites, including $\mathrm{LTB}_{4}$ and PGs, were associated with inflammatory responses and bile acid metabolism [134]. An animal study based on NC/Nga mice demonstrated that treatment with docosahexaenoic acid (DHA)/eicosapentaenoic acid (EPA) and FK506 reduced the clinical scores for dermatitis and lowered local $\mathrm{LTB}_{4}$ concentrations, suggesting that DHA/EPA might be effective against skin inflammation in AD by suppressing local $\mathrm{LTB}_{4}$ production [135].

Recent studies show that $\mathrm{LTB}_{4}$ and CysLTs play important but distinct roles in the pathogenesis of $\mathrm{AD}$. $\mathrm{LTB}_{4}$ is implicated in recruitment of neutrophils and Th2 cells, and it is thought to be pivotal for the pathogenesis of acute inflammation in both human and murine models of $\mathrm{AD}[136,137]$. CysLTs, on the other hand, are implicated in chronic inflammatory characteristics of $\mathrm{AD}$, including collagen deposition, skin thickening, and fibrosis, all of which are typical of chronic AD [138]. Thus, it follows that therapies targeting $\mathrm{LTB}_{4}$ or CysLTs might be promising for management of AD. However, montelukast has questionable efficacy in patients with $\mathrm{AD}$; randomized controlled trials demonstrate limited and contradictory evidence regarding the efficacy of montelukast compared with placebo, with larger trials suggesting no clinically significant effect [139-141]. Meanwhile, small pilot studies using oral zileuton show some potential efficacy in humans and canines [142,143]. Since these studies were limited in size, they should be interpreted with caution. Larger-scaled clinical research is needed before a definitive conclusion can be drawn. However, development of eicosanoid-directed therapies specifically targeting the pathophysiology underlying AD will be important.

Several agents that target LTs and/or PGs are in development. These include OC000459, Q301, and ZPL-521. Timapiprant (OC000459), a novel oral antagonist for chemoattractant receptor-homologous molecules expressed by Th2 cells (CRTH2), has proven to be safe and effective for management of asthma [144]; however, it failed to show efficacy against AD in clinical trials (https://clinicaltrials. gov/ct2/show/NCT02002208). Q301 (Qurient, Gyoenggi-do, Republic of Korea) is a novel topical zileuton cream [Nam, KY, Kim, JJ, OH, SH, et al. (2016). Topical anti-inflammatory pharmaceutical 
composition with zileuton cream formulation. US patent application 20160228353]. Although clinical trials failed to show significant efficacy of montelukast against $A D$, intervention in the $\mathrm{LTB}_{4}-\mathrm{BLT} 1$ pathway via 5-LO inhibition might be effective since $\mathrm{LTB}_{4}$ seems to be the most potent LT with respect to triggering the proinflammatory cascade and recruitment of Th2 cells; by contrast, CysLTs are involved in the chronic inflammatory course of $\mathrm{AD}$ [136-138]. A phase 2 clinical trial measuring safety and efficacy of Q301 with respect to moderate-to-severe AD (NCT02426359) was completed recently (https://clinicaltrials.gov/ct2/show/NCT02426359). It remains unclear whether anti-LT therapy using oral zileuton or topical Q301 will be clinically significant, but these therapeutic options might provide some symptomatic relief.

A novel $\mathrm{CPLA}_{2}$ inhibitor reduces allergic inflammation in an in vitro model of asthma [145]. ZPL-521 (Ziarco, Canterbury, UK), a topical formulation of this CPLA $_{2}$ inhibitor, has completed phase 1 and 2 clinical trials (NCT02795832) to evaluate its safety and efficacy when used to treat moderate-to-severe AD (https://clinicaltrials.gov/ct2/show/NCT02795832). The results remain to be seen. The interactions between LTs and PGs during the pathogenesis of AD are complex, and broad downregulation of the AA pathway would certainly lead to a reduction in levels of proinflammatory LTs and PGs; however, this approach also inhibits regulatory interactions, such as $\mathrm{PGD}_{2}-\mathrm{DP} 1$ signaling.

Overall, eicosanoids such as LTs and PGs are involved in a number of complex pathophysiologic changes seen in the skin of patients with AD. Medications targeting LTs will provide a therapeutic avenue for patients suffering from moderate-to-severe AD. Several medications are in the developmental pipeline, although their efficacy remains to be determined; these topical agents may become effective maintenance treatments or flare prophylactics for those with AD (similar to antileukotrienes for asthma) [146].

\subsection{Allergic Conjunctivitis}

Ocular itching, lacrimation, and redness are common symptoms of allergic conjunctivitis, which is usually considered a comorbidity associated with AR. Ocular allergy occurs through activation of Th2 cell-mediated cascades, leading to production of IgE; it can also occur in combination with T lymphocyte-mediated disorders, with subsequent development of acute and chronic forms of ocular allergy. This proinflammatory state caused by activation of transcription factors creates an immune cascade via increased cellular infiltration (e.g., eosinophils) and secretion of chemokines, cytokines, and metalloproteinases, which further promotes ocular surface damage and disruption of epithelial barriers [147].

$\mathrm{LTB}_{4}$ was first shown to cause eosinophil migration into conjunctival tissue in a guinea pig model. Combination therapy with an SAH and a 5-LO inhibitor results in near-complete suppression of allergic conjunctivitis in this model [148]. Involvement of the $\mathrm{LTB}_{4}-\mathrm{BLT1}$ pathway in the pathophysiology of allergic conjunctivitis was further demonstrated in a mouse model of ocular allergy in which the BLT1 antagonist ONO-4057 inhibited ocular scratching behavior induced by challenge with ragweed pollen [149]. $\mathrm{LTB}_{4}$ is also involved in secondary allergic conjunctivitis; indeed, a recent study investigating changes in the concentration of inflammatory mediators (including histamine and LTs) in tears of those with secondary allergic conjunctivitis due to primary allergic reactions in the nasal mucosa revealed involvement of $\mathrm{LTB}_{4}$ in both late and delayed-type secondary allergic conjunctivitis [150].

One of the main mechanisms underlying the pathogenesis of allergic conjunctivitis is increased secretion of mucin by goblet cells. Both CysLT1 and CysLT2 are expressed by rat conjunctiva and in cultured rat and human conjunctival goblet cells. Treatment with the CysLT1 antagonist MK571 led to a marked reduction in the amount of mucin secreted by LTD $_{4}$-stimulated goblet cells [151]. Involvement of the CysLTs pathway in allergic conjunctivitis was also indicated in a clinical trial of orally administered montelukast in patients with both vernal keratoconjunctivitis and asthma; the trial reported a reduction in the severity of ocular signs and symptoms [152]. 
There are limited approved therapeutic options for treatment of allergic conjunctivitis. Of interest, it was confirmed that the nonpharmacological interventions of artificial tears and the use of cold compresses alone or in combination often provide patients with significant benefits [147]. In the area of pharmacotherapy, there has been one new approval of an antihistamine, cetirizine. Considering that the $\mathrm{LTB}_{4}$-BLT1 pathway is involved in the pathophysiology of allergic conjunctivitis, the therapeutic use of BLT1 antagonists in addition to antihistamines may offer more effective treatment.

\subsection{Anaphylaxis}

Anaphylaxis is a life-threatening allergic reaction in which an antigen binds to $\operatorname{IgE}$ and activates MCs and basophils, leading to massive release of inflammatory mediators [153]. The resulting increase in vascular permeability exacerbates the symptoms. Increased $\mathrm{LTE}_{4}$ levels are associated with anaphylaxis [154]. MCs are thought to be the main source of CysLTs during anaphylactic reactions $[155,156]$.

An animal study demonstrated reduced extravasation of plasma proteins in CysLT1-deficient mice undergoing IgE-mediated passive cutaneous anaphylaxis [155]. By contrast, CysLT2 transgenic mice showed increased vascular permeability in response to endogenous CysLTs produced by activated MCs during passive cutaneous anaphylaxis [43]. Both of these animal studies suggest that the CysLTs pathway, at least under certain conditions, regulates endothelial integrity.

MC activation disorders include mastocytosis (a spectrum of rare and well-defined diseases associated with clonal expansion of MCs in the skin and/or other tissues and organs) and MC activation syndrome (MCAS) (a rare condition defined by acute and/or chronic symptoms of MC activation with elevation of MC mediators at baseline or during acute episodes, without MC hyperplasia) [157]. Primary MC activation disorders are caused by intrinsic proliferation or clonal expansion of MCs and are associated typically with KIT mutations, represented by cutaneous or systemic mastocytosis (CM or SM) and monoclonal MCAS [158]. Secondary MC disorders are associated with allergic and other inflammatory or autoimmune disorders.

Symptoms associated with MC activation arise secondary to tissue responses to inflammatory mediators such as tryptase, histamine, PGs, LTs, and cytokines as well as the local MC burden in patients with mastocytosis [159]. Symptoms can be managed by blocking mediator receptors (H1and H2-antihistamines and LT receptors), inhibiting mediator synthesis (aspirin and zileuton) and mediator release (sodium cromolyn), or instigating anti-IgE therapy, or a combination of these.

As stated below, measurement of urinary levels of excreted $\mathrm{LTE}_{4}$, the stable CysLT derivative of $\mathrm{LTC}_{4}$, can be used to quantitate whole-body production of CysLTs, which reflects short-term changes in secretion [154]. MCs, basophils, and eosinophils synthesize LTs, which are also produced by platelets and endothelial cells via transcellular biosynthesis [160]. A 5.5- to 52-fold increase in urinary CysLT has been reported during anaphylactic reactions [161]. More prominent elevation of urinary $\mathrm{LTE}_{4}$ levels was observed among patients with SM, than among nonmastocytosis populations with symptoms ascribed to excessive release of MC mediators (e.g., chronic urticaria, idiopathic angioedema, and drug allergy) [154].

Pathophysiological roles of leukotrienes and antileukotriene strategy for allergic diseases in clinical and experimental settings are described in Table 1. 
Table 1. Pathophysiological roles of leukotrienes and treatment strategies for allergic diseases.

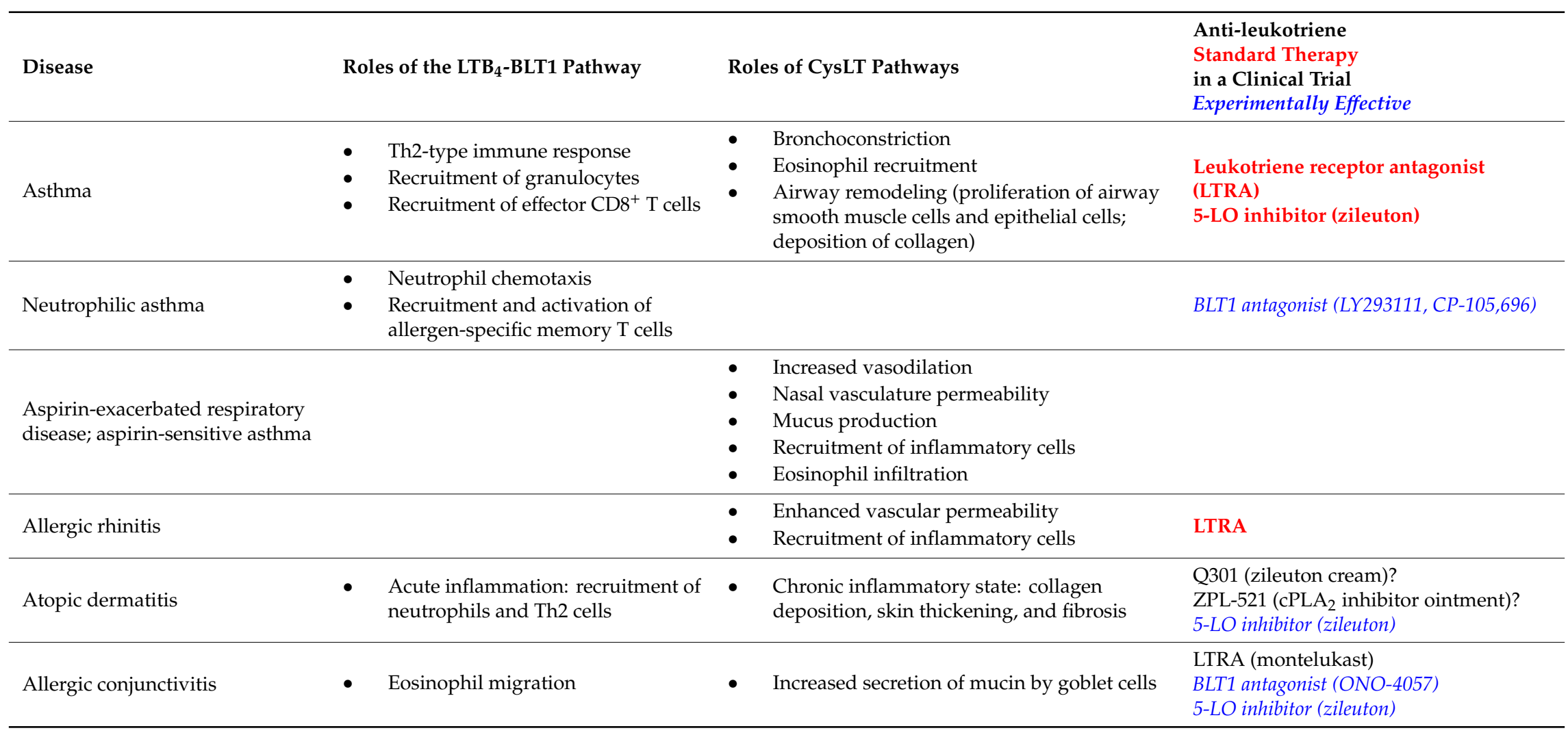




\section{Urinary $\mathrm{LTE}_{4}$ as a Biomarker of Allergic Disease}

Measurement of urinary $\mathrm{LTE}_{4}\left(\mathrm{uLTE}_{4}\right)$, the stable CysLT derivative of $\mathrm{LTC}_{4}$, can be a useful noninvasive method for measuring whole-body CysLT levels; indeed, it is a biomarker of total production and excretion of CysLTs. The level of $\mathrm{LTE}_{4}$ in serum is too low to measure. Studies show that inhalation of $\mathrm{LTC}_{4}$ or $\mathrm{LTD}_{4}$ leads to a dose-dependent increase in $\mathrm{uLTE}_{4}$ levels [162]. Approximately $5 \%$ of inhaled CysLTs were excreted in urine [163], almost all in the form of $\mathrm{uLTE}_{4}$ [47].

Mass spectrometry is the gold standard for measurement of $\mathrm{uLTE}_{4}$ because it has a low coefficient of variation and almost $100 \%$ recovery from spiked samples, indicating high sensitivity and precision $[164,165]$. The measurement is expressed in terms of picograms of $\mathrm{LTE}_{4}$ per milligram of creatinine (Cr); the reference range among normal volunteers is $<104 \mathrm{pg} / \mathrm{mg} \mathrm{Cr}$ [165]. Increased urinary levels of $\mathrm{LTE}_{4}$ are reported in several conditions, including AERD [166], in which MC activation occurs.

Overall, measurement of $\mathrm{uLTE}_{4}$ is a sensitive and noninvasive method of assaying total body production of CysLTs and is a useful biomarker of exposure to atopic and nonatopic asthma triggers [47,167], recent asthma exacerbations [168], AERD [166,169], early development of childhood atopy $[170,171]$, and obstructive sleep apnea $[172,173]$; it is also useful for predicting susceptibility to LT receptor antagonists [174-176].

\section{Other Diseases}

LT signaling is involved in the pathogenesis/pathophysiology of various diseases other than allergic diseases. Studies demonstrate involvement of $\mathrm{LTB}_{4}-\mathrm{BLT} 1$ signaling in the pathogenesis/pathophysiology of endotoxin shock [177], rheumatoid arthritis [178], inflammatory colitis [13,179], alveolar bone loss [180], osteoporosis [181], epidermolysis bullosa acquisita [182], contact dermatitis [183,184], psoriasis [185], and silica-induced lung cancer $[8,186]$. In addition, our recent study revealed that M2 macrophages expressing BLT1 augment neovascularization in a mouse model of AMD, indicating involvement of $\mathrm{LTB}_{4}-\mathrm{BLT} 1$ signaling in disease pathogenesis and strongly suggesting a potential novel therapeutic target for neovascularization [187]. Damaged retinal pigment epithelial cells release $\mathrm{LTB}_{4}$, which recruits immune cells such as neutrophils and inflammatory monocytes/macrophages to the injured retina. An autocrine/paracrine loop of $\mathrm{LTB}_{4}$ production in these cells leads to formation of an inflammatory environment. Among these cells, M2 macrophages secrete VEGF-A, which accelerates choroidal neovascularization (Figure 2).

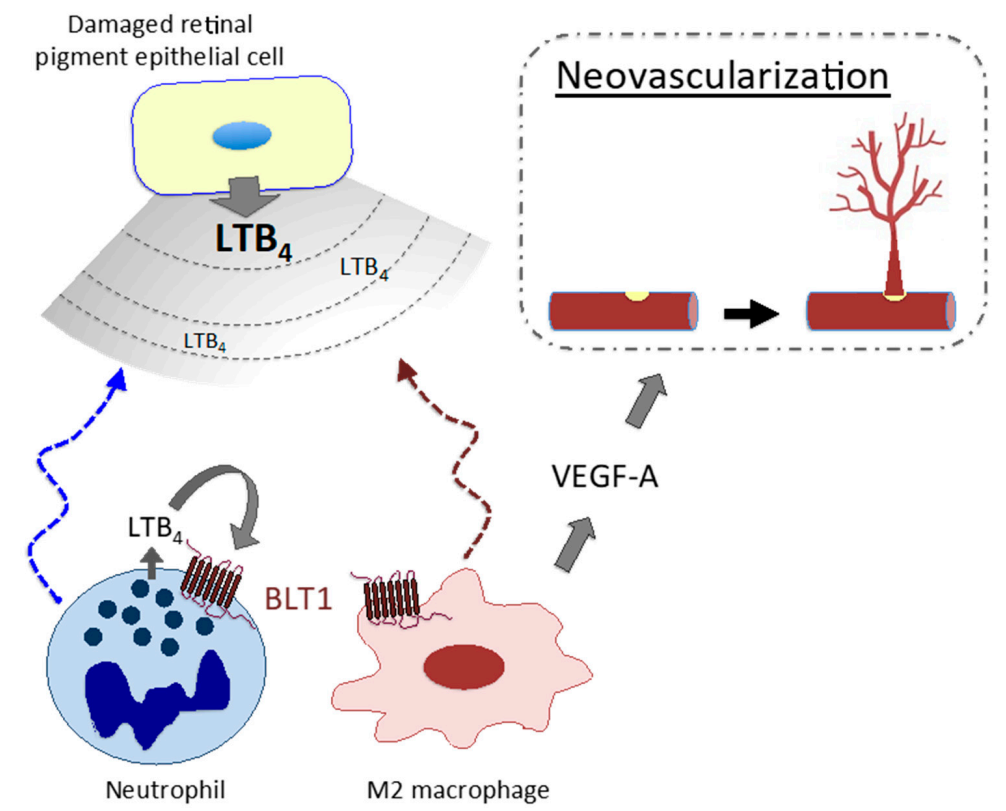

Figure 2. M2 macrophages promote abnormal (pathogenic) neovascularization in age-related macular degeneration via the $\mathrm{LTB}_{4}-\mathrm{BLT} 1$ signaling pathway. 


\section{Conclusions}

In this review, we first summarized the biosynthetic and metabolic pathways of LTs and described expression and signaling pathways of leukotriene receptors (Figure 1). Next, we discussed the pathophysiological roles of LTs in allergic diseases and provided up-to-date information obtained from both experimental and clinical settings. Meanwhile antileukotriene treatment has become standard therapy for some allergic diseases, several clinical trials are ongoing, and animal studies suggest further applications for anti-LT strategies in many allergic conditions. Because LTs play a major role in the pathophysiology of acute and chronic inflammation (i.e., neutrophil recruitment and airway remodeling), targeting their signaling pathways should be a promising therapeutic option for various allergic diseases.

Conflicts of Interest: The authors declare no conflict of interest.

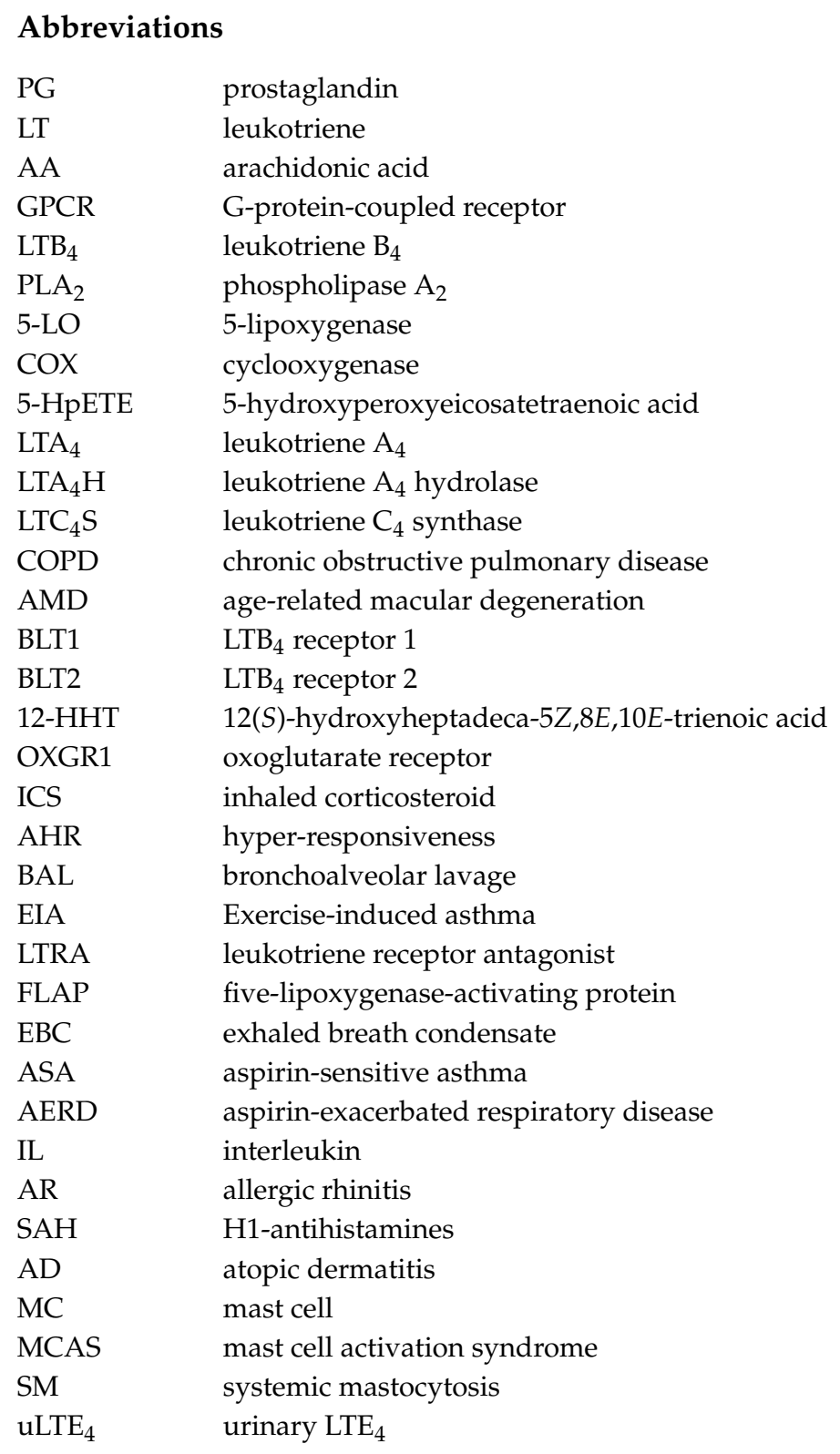




\section{References}

1. Shimizu, T. Lipid mediators in health and disease: Enzymes and receptors as therapeutic targets for the regulation of immunity and inflammation. Annu. Rev. Pharmacol. Toxicol. 2009, 49, 123-150. [CrossRef] [PubMed]

2. Radmark, O.; Werz, O. 5-Lipoxygenase, a key enzyme for leukotriene biosynthesis in health and disease. Biochim. Biophys. Acta 2015, 1851, 331-339. [CrossRef] [PubMed]

3. Back, M.; Powell, W.S. Update on leukotriene, lipoxin and oxoeicosanoid receptors: IUPHAR Review 7. Br. J. Pharmacol. 2014, 171, 3551-3574. [CrossRef] [PubMed]

4. Liu, M.; Yokomizo, T. The role of leukotrienes in allergic diseases. Allergol. Int. 2015, 64, 17-26. [CrossRef] [PubMed]

5. Haeggstrom, J.Z.; Funk, C.D. Lipoxygenase and leukotriene pathways: Biochemistry, biology, and roles in disease. Chem. Rev. 2011, 111, 5866-5898. [CrossRef] [PubMed]

6. White, A.A.; Stevenson, D.D. Aspirin-Exacerbated Respiratory Disease. N. Engl. J. Med. 2018, 379, $1060-1070$. [CrossRef]

7. Cuzzo, B.; Lappin, S.L. Physiology, Leukotrienes; StatPearls: Treasure Island, FL, USA, 2019.

8. Satpathy, S.R.; Jala, V.R. Crystalline silica-induced leukotriene B4-dependent inflammation promotes lung tumour growth. Nat. Commun. 2015, 6, 7064. [CrossRef]

9. Jala, V.R.; Bodduluri, S.R. The yin and yang of leukotriene B4 mediated inflammation in cancer. Semin. Immunol. 2017, 33, 58-64. [CrossRef]

10. Park, J.; Jang, J.H. BLT2, a leukotriene B4 receptor 2, as a novel prognostic biomarker of triple-negative breast cancer. BMB Rep. 2018, 51, 373-377. [CrossRef]

11. Houthuijzen, J.M.; Daenen, L.G. Lysophospholipids secreted by splenic macrophages induce chemotherapy resistance via interference with the DNA damage response. Nat. Commun. 2014, 5, 5275. [CrossRef]

12. Mathis, S.P.; Jala, V.R. Nonredundant roles for leukotriene B4 receptors BLT1 and BLT2 in inflammatory arthritis. J. Immunol. 2010, 185, 3049-3056. [CrossRef] [PubMed]

13. Iizuka, Y.; Okuno, T. Protective role of the leukotriene B4 receptor BLT2 in murine inflammatory colitis. FASEB J. 2010, 24, 4678-4690. [CrossRef] [PubMed]

14. Paruchuri, S.; Tashimo, H. Leukotriene E4-induced pulmonary inflammation is mediated by the P2Y12 receptor. J. Exp. Med. 2009, 206, 2543-2555. [CrossRef] [PubMed]

15. Foster, H.R.; Fuerst, E. Characterisation of P2Y(12) receptor responsiveness to cysteinyl leukotrienes. PLoS ONE 2013, 8, e58305. [CrossRef] [PubMed]

16. Bankova, L.G.; Lai, J. Leukotriene E4 elicits respiratory epithelial cell mucin release through the G-protein-coupled receptor, GPR99. Proc. Natl. Acad. Sci. USA 2016, 113, 6242-6247. [CrossRef] [PubMed]

17. Ciana, P.; Fumagalli, M. The orphan receptor GPR17 identified as a new dual uracil nucleotides/cysteinyl-leukotrienes receptor. EMBO J. 2006, 25, 4615-4627. [CrossRef]

18. Davenport, A.P.; Alexander, S.P. International Union of Basic and Clinical Pharmacology. LXXXVIII. G protein-coupled receptor list: Recommendations for new pairings with cognate ligands. Pharmacol. Rev. 2013, 65, 967-986. [CrossRef]

19. Krishnamoorthy, S.; Recchiuti, A. Resolvin D1 binds human phagocytes with evidence for proresolving receptors. Proc. Natl. Acad. Sci. USA 2010, 107, 1660-1665. [CrossRef]

20. Chiang, N.; Fredman, G. Infection regulates pro-resolving mediators that lower antibiotic requirements. Nature 2012, 484, 524-528. [CrossRef]

21. Dalli, J.; Winkler, J.W. Resolvin D3 and aspirin-triggered resolvin D3 are potent immunoresolvents. Chem. Biol. 2013, 20, 188-201. [CrossRef]

22. Wittamer, V.; Gregoire, F. The C-terminal nonapeptide of mature chemerin activates the chemerin receptor with low nanomolar potency. J. Biol. Chem. 2004, 279, 9956-9962. [CrossRef] [PubMed]

23. Wittamer, V.; Franssen, J.D. Specific recruitment of antigen-presenting cells by chemerin, a novel processed ligand from human inflammatory fluids. J. Exp. Med. 2003, 198, 977-985. [CrossRef] [PubMed]

24. Arita, M.; Bianchini, F. Stereochemical assignment, antiinflammatory properties, and receptor for the omega-3 lipid mediator resolvin E1. J. Exp. Med. 2005, 201, 713-722. [CrossRef] [PubMed] 
25. Yokomizo, T. Two distinct leukotriene B4 receptors, BLT1 and BLT2. J. BioChem. 2015, 157, 65-71. [CrossRef] [PubMed]

26. Yokomizo, T.; Izumi, T. A G-protein-coupled receptor for leukotriene B4 that mediates chemotaxis. Nature 1997, 387, 620-624. [CrossRef]

27. Qiu, H.; Johansson, A.S. Differential induction of BLT receptor expression on human endothelial cells by lipopolysaccharide, cytokines, and leukotriene B4. Proc. Natl. Acad. Sci. USA 2006, 103, 6913-6918. [CrossRef] [PubMed]

28. Wada, K.; Arita, M. Leukotriene B4 and lipoxin A4 are regulatory signals for neural stem cell proliferation and differentiation. FASEB J. 2006, 20, 1785-1792. [CrossRef]

29. Sun, R.; Ba, X. Leukotriene B4 regulates proliferation and differentiation of cultured rat myoblasts via the BLT1 pathway. Mol. Cells 2009, 27, 403-408. [CrossRef]

30. Yokomizo, T.; Kato, K. A second leukotriene B(4) receptor, BLT2. A new therapeutic target in inflammation and immunological disorders. J. Exp. Med. 2000, 192, 421-432. [CrossRef]

31. Yokomizo, T.; Ogawa, Y. cDNA cloning, expression, and mutagenesis study of leukotriene B4 12-hydroxydehydrogenase. J. Biol. Chem. 1996, 271, 2844-2850. [CrossRef]

32. Okuno, T.; Iizuka, Y. 12(S)-Hydroxyheptadeca-5Z, 8E, 10E-trienoic acid is a natural ligand for leukotriene B4 receptor 2. J. Exp. Med. 2008, 205, 759-766. [CrossRef] [PubMed]

33. Liu, M.; Saeki, K. 12-Hydroxyheptadecatrienoic acid promotes epidermal wound healing by accelerating keratinocyte migration via the BLT2 receptor. J. Exp. Med. 2014, 211, 1063-1078. [CrossRef] [PubMed]

34. Iwamoto, S.; Koga, T. Non-steroidal anti-inflammatory drug delays corneal wound healing by reducing production of 12-hydroxyheptadecatrienoic acid, a ligand for leukotriene B4 receptor 2. Sci. Rep. 2017, 7, 13267. [CrossRef] [PubMed]

35. Shigematsu, M.; Koga, T. Leukotriene B4 receptor type 2 protects against pneumolysin-dependent acute lung injury. Sci. Rep. 2016, 6, 34560. [CrossRef] [PubMed]

36. Saeki, K.; Yokomizo, T. Identification, signaling, and functions of LTB4 receptors. Semin. Immunol. 2017, 33, 30-36. [CrossRef] [PubMed]

37. Thompson-Souza, G.A.; Gropillo, I. Cysteinyl Leukotrienes in Eosinophil Biology: Functional Roles and Therapeutic Perspectives in Eosinophilic Disorders. Front. Med. (Lausanne) 2017, 4, 106. [CrossRef]

38. Wunder, F.; Tinel, H. Pharmacological characterization of the first potent and selective antagonist at the cysteinyl leukotriene 2 (CysLT(2)) receptor. Br. J. Pharmacol. 2010, 160, 399-409. [CrossRef] [PubMed]

39. Lynch, K.R.; O'Neill, G.P. Characterization of the human cysteinyl leukotriene CysLT1 receptor. Nature 1999, 399, 789-793. [CrossRef]

40. Heise, C.E.; O'Dowd, B.F. Characterization of the human cysteinyl leukotriene 2 receptor. J. Biol. Chem. 2000, 275, 30531-30536. [CrossRef]

41. Mechiche, H.; Naline, E. Effects of cysteinyl leukotrienes in small human bronchus and antagonist activity of montelukast and its metabolites. Clin. Exp. Allergy 2003, 33, 887-894. [CrossRef]

42. Figueroa, D.J.; Breyer, R.M. Expression of the cysteinyl leukotriene 1 receptor in normal human lung and peripheral blood leukocytes. Am. J. Respir. Crit. Care Med. 2001, 163, 226-233. [CrossRef] [PubMed]

43. Hui, Y.; Cheng, Y. Directed vascular expression of human cysteinyl leukotriene 2 receptor modulates endothelial permeability and systemic blood pressure. Circulation 2004, 110, 3360-3366. [CrossRef] [PubMed]

44. Maekawa, A.; Kanaoka, Y. Functional recognition of a distinct receptor preferential for leukotriene E4 in mice lacking the cysteinyl leukotriene 1 and 2 receptors. Proc. Natl. Acad. Sci. USA 2008, 105, 16695-16700. [CrossRef] [PubMed]

45. Kanaoka, Y.; Maekawa, A. Identification of GPR99 protein as a potential third cysteinyl leukotriene receptor with a preference for leukotriene E4 ligand. J. Biol. Chem. 2013, 288, 10967-10972. [CrossRef] [PubMed]

46. Shirasaki, H.; Kanaizumi, E. Expression and localization of GPR99 in human nasal mucosa. Auris Nasus Larynx 2017, 44, 162-167. [CrossRef] [PubMed]

47. Hoffman, B.C.; Rabinovitch, N. Urinary Leukotriene E4 as a Biomarker of Exposure, Susceptibility, and Risk in Asthma: An Update. Immunol. Allergy Clin. N. Am. 2018, 38, 599-610. [CrossRef] [PubMed]

48. Peebles, R.S., Jr.; Aronica, M.A. Proinflammatory Pathways in the Pathogenesis of Asthma. Clin. Chest Med. 2019, 40, 29-50. [CrossRef] [PubMed]

49. Gelfand, E.W. Importance of the leukotriene B4-BLT1 and LTB4-BLT2 pathways in asthma. Semin. Immunol. 2017, 33, 44-51. [CrossRef] 
50. Miligkos, M.; Bannuru, R.R. Leukotriene-receptor antagonists versus placebo in the treatment of asthma in adults and adolescents: A systematic review and meta-analysis. Ann. Intern. Med. 2015, 163, 756-767. [CrossRef]

51. Bruno, F.; Spaziano, G. Recent advances in the search for novel 5-lipoxygenase inhibitors for the treatment of asthma. Eur. J. Med. Chem. 2018, 153, 65-72. [CrossRef]

52. Matsunaga, Y.; Fukuyama, S. Leukotriene B4 receptor BLT2 negatively regulates allergic airway eosinophilia. FASEB J. 2013, 27, 3306-3314. [CrossRef] [PubMed]

53. Kandhare, A.D.; Liu, Z. Therapeutic Potential of Morin in Ovalbumin-induced Allergic Asthma Via Modulation of SUMF2/IL-13 and BLT2/NF-kB Signaling Pathway. Curr. Mol. Pharmacol. 2019, 12, 122-138. [CrossRef] [PubMed]

54. Liu, M.; Shen, J. Leukotriene B4 receptor 2 regulates the proliferation, migration, and barrier integrity of bronchial epithelial cells. J. Cell. Physiol. 2018, 233, 6117-6124. [CrossRef] [PubMed]

55. Seymour, M.L.; Rak, S. Leukotriene and prostanoid pathway enzymes in bronchial biopsies of seasonal allergic asthmatics. Am. J. Respir. Crit. Care Med. 2001, 164, 2051-2056. [CrossRef] [PubMed]

56. Zaitsu, M.; Hamasaki, Y. Leukotriene synthesis is increased by transcriptional up-regulation of 5-lipoxygenase, leukotriene A4 hydrolase, and leukotriene C4 synthase in asthmatic children. J. Asthma 2003, 40, 147-154. [CrossRef] [PubMed]

57. Pal, K.; Feng, X. Leukotriene A4 Hydrolase Activation and Leukotriene B4 Production by Eosinophils in Severe Asthma. Am. J. Respir. Cell Mol. Biol. 2019, 60, 413-419. [CrossRef] [PubMed]

58. Kazani, S.; Planaguma, A. Exhaled breath condensate eicosanoid levels associate with asthma and its severity. J. Allergy Clin. Immunol. 2013, 132, 547-553. [CrossRef]

59. Trischler, J.; Muller, C.M. Elevated exhaled leukotriene B(4) in the small airway compartment in children with asthma. Ann. Allergy Asthma Immunol. 2015, 114, 111-116. [CrossRef]

60. Ohnishi, H.; Miyahara, N. The role of leukotriene B(4) in allergic diseases. Allergol. Int. 2008, 57, $291-298$. [CrossRef]

61. Loutsios, C.; Farahi, N. Biomarkers of eosinophilic inflammation in asthma. Expert Rev. Respir. Med. 2014, 8, 143-150. [CrossRef]

62. Ito, K.; Herbert, C. Steroid-resistant neutrophilic inflammation in a mouse model of an acute exacerbation of asthma. Am. J. Respir. Cell Mol. Biol. 2008, 39, 543-550. [CrossRef] [PubMed]

63. Wang, F.; He, X.Y. Different inflammatory phenotypes in adults and children with acute asthma. Eur. Respir. J. 2011, 38, 567-574. [CrossRef] [PubMed]

64. Panettieri, R.A., Jr. Neutrophilic and Pauci-immune Phenotypes in Severe Asthma. Immunol. Allergy Clin. N. Am. 2016, 36, 569-579. [CrossRef] [PubMed]

65. Chang, H.S.; Lee, T.H. Neutrophilic inflammation in asthma: Mechanisms and therapeutic considerations. Expert Rev. Respir. Med. 2017, 11, 29-40. [CrossRef] [PubMed]

66. Ray, A.; Kolls, J.K. Neutrophilic Inflammation in Asthma and Association with Disease Severity. Trends Immunol. 2017, 38, 942-954. [CrossRef]

67. Moore, W.C.; Hastie, A.T. Sputum neutrophil counts are associated with more severe asthma phenotypes using cluster analysis. J. Allergy Clin. Immunol. 2014, 133, 1557-1563.e5. [CrossRef]

68. Simpson, J.L.; Guest, M. Occupational exposures, smoking and airway inflammation in refractory asthma. BMC Pulm. Med. 2014, 14, 207. [CrossRef]

69. Carroll, N.; Carello, S. Airway structure and inflammatory cells in fatal attacks of asthma. Eur. Respir. J. 1996, 9, 709-715. [CrossRef]

70. Sur, S.; Crotty, T.B. Sudden-onset fatal asthma. A distinct entity with few eosinophils and relatively more neutrophils in the airway submucosa? Am. Rev. Respir. Dis. 1993, 148, 713-719. [CrossRef]

71. Xiong, Y.; Cui, X. BLT1 signaling in epithelial cells mediates allergic sensitization via promotion of IL-33 production. Allergy 2019, 74, 495-506. [CrossRef]

72. Gelfand, E.W.; Alam, R. The other side of asthma: Steroid-refractory disease in the absence of TH2-mediated inflammation. J. Allergy Clin. Immunol. 2015, 135, 1196-1198. [CrossRef] [PubMed]

73. Medoff, B.D.; Tager, A.M. Antibody-antigen interaction in the airway drives early granulocyte recruitment through BLT1. Am. J. Physiol Lung Cell Mol. Physiol. 2006, 290, L170-L178. [CrossRef] [PubMed]

74. Miyahara, N.; Takeda, K. Leukotriene B4 receptor-1 is essential for allergen-mediated recruitment of CD8+ T cells and airway hyperresponsiveness. J. Immunol. 2005, 174, 4979-4984. [CrossRef] [PubMed] 
75. Miyahara, N.; Ohnishi, H. Leukotriene B4 receptor 1 expression on dendritic cells is required for the development of Th2 responses and allergen-induced airway hyperresponsiveness. J. Immunol. 2008, 181, 1170-1178. [CrossRef] [PubMed]

76. Ohnishi, H.; Miyahara, N. Corticosteroids enhance CD8+ T cell-mediated airway hyperresponsiveness and allergic inflammation by upregulating leukotriene B4 receptor 1. J. Allergy Clin. Immunol. 2008, 121, 864-871.e4. [CrossRef]

77. Gelfand, E.W.; Dakhama, A. CD8+ T lymphocytes and leukotriene B4: Novel interactions in the persistence and progression of asthma. J. Allergy Clin. Immunol. 2006, 117, 577-582. [CrossRef] [PubMed]

78. Evans, D.J.; Barnes, P.J. Effect of a leukotriene B4 receptor antagonist, LY293111, on allergen induced responses in asthma. Thorax 1996, 51, 1178-1184. [CrossRef]

79. Asanuma, F.; Kuwabara, K. Effects of leukotriene B4 receptor antagonist, LY293111Na, on antigen-induced bronchial hyperresponsiveness and leukocyte infiltration in sensitized guinea pigs. Inflamm. Res. 2001, 50, 136-141. [CrossRef]

80. Turner, C.R.; Breslow, R. In vitro and in vivo effects of leukotriene B4 antagonism in a primate model of asthma. J. Clin. Investig. 1996, 97, 381-387. [CrossRef]

81. Elieh Ali Komi, D.; Bjermer, L. Mast Cell-Mediated Orchestration of the Immune Responses in Human Allergic Asthma: Current Insights. Clin. Rev. Allergy Immunol. 2019, 56, 234-247. [CrossRef]

82. Kouyama, S.; Otomo-Abe, A. A contraction assay system using primary cultured mouse bronchial smooth muscle cells. Int. Arch. Allergy Immunol. 2013, 161 (Suppl. 2), 93-97. [CrossRef]

83. Yokomizo, T.; Nakamura, M. Leukotriene receptors as potential therapeutic targets. J. Clin. Investig. 2018, 128, 2691-2701. [CrossRef] [PubMed]

84. Williams, A.M.; Phaneuf, D.J. Short-term impact of PM2.5 on contemporaneous asthma medication use: Behavior and the value of pollution reductions. Proc. Natl. Acad. Sci. USA 2019, 116, 5246-5253. [CrossRef] [PubMed]

85. Rabinovitch, N.; Jones, M.J. Cysteinyl Leukotriene Receptor 1 and Health Effects of Particulate Exposure in Asthma. Ann. Am. Thorac. Soc. 2018, 15, S129. [CrossRef] [PubMed]

86. Fregonese, L.; Silvestri, M. Cysteinyl leukotrienes induce human eosinophil locomotion and adhesion molecule expression via a CysLT1 receptor-mediated mechanism. Clin. Exp. Allergy 2002, 32, 745-750. [CrossRef] [PubMed]

87. Shirasaki, H.; Kanaizumi, E. Leukotriene D4 induces chemotaxis in human eosinophilc cell line, EoL-1 cells via CysLT1 receptor activation. Heliyon 2017, 3, e00464. [CrossRef] [PubMed]

88. Chan, C.C.; McKee, K. Eosinophil-eicosanoid interactions: Inhibition of eosinophil chemotaxis in vivo by a LTD4-receptor antagonist. Eur. J. Pharmacol. 1990, 191, 273-280.

89. Laitinen, L.A.; Laitinen, A. Leukotriene E4 and granulocytic infiltration into asthmatic airways. Lancet 1993, 341, 989-990. [CrossRef]

90. Wang, H.B.; Akuthota, P. Airway eosinophil migration into lymph nodes in mice depends on leukotriene C4. Allergy 2017, 72, 927-936. [CrossRef]

91. Liu, T.; Garofalo, D. Platelet-driven leukotriene C4-mediated airway inflammation in mice is aspirin-sensitive and depends on T prostanoid receptors. J. Immunol. 2015, 194, 5061-5068. [CrossRef]

92. Ilmarinen, P.; Kankaanranta, H. Eosinophil apoptosis as a therapeutic target in allergic asthma. Basic Clin. Pharmacol. Toxicol. 2014, 114, 109-117. [CrossRef] [PubMed]

93. Duah, E.; Adapala, R.K. Cysteinyl leukotrienes regulate endothelial cell inflammatory and proliferative signals through CysLT(2) and CysLT(1) receptors. Sci. Rep. 2013, 3, 3274. [CrossRef] [PubMed]

94. Mauser, P.J.; House, A. Pharmacological characterization of the late phase reduction in lung functions and correlations with microvascular leakage and lung edema in allergen-challenged Brown Norway rats. Pulm. Pharmacol. Ther. 2013, 26, 677-684. [CrossRef] [PubMed]

95. Parameswaran, K.; Radford, K. Modulation of human airway smooth muscle migration by lipid mediators and Th-2 cytokines. Am. J. Respir. Cell Mol. Biol. 2007, 37, 240-247. [CrossRef] [PubMed]

96. Dholia, N.; Yadav, U.C.S. Lipid mediator Leukotriene D4-induces airway epithelial cells proliferation through EGFR/ERK1/2 pathway. Prostaglandins Other Lipid Mediat. 2018, 136, 55-63. [CrossRef]

97. Holgate, S.T.; Peters-Golden, M. Roles of cysteinyl leukotrienes in airway inflammation, smooth muscle function, and remodeling. J. Allergy Clin. Immunol. 2003, 111, S18-S34; discussion S34-S16. [CrossRef] 
98. Mehrotra, A.K.; Henderson, W.R., Jr. The role of leukotrienes in airway remodeling. Curr. Mol. Med. 2009, 9, 383-391. [CrossRef]

99. Matsuda, M.; Tabuchi, Y. Increased expression of CysLT2 receptors in the lung of asthmatic mice and role in allergic responses. Prostaglandins Leukot. Essent. Fatty Acids 2018, 131, 24-31. [CrossRef]

100. Worrell, K.; Shaw, M.R. A systematic review of the literature on screening for exercise-induced asthma: Considerations for school nurses. J. Sch. Nurs. 2015, 31, 70-76. [CrossRef]

101. Roche, A.; Ahmareen, O. The role of leukotriene receptor antagonists in exercise induced bronchoconstriction in children. Diagnosis 2014, 1, 213-222. [CrossRef]

102. Tamada, T.; Ichinose, M. Leukotriene Receptor Antagonists and Antiallergy Drugs. Handb. Exp. Pharmacol. 2017, 237, 153-169. [CrossRef] [PubMed]

103. Hilberg, T.; Deigner, H.P. Transcription in response to physical stress-clues to the molecular mechanisms of exercise-induced asthma. FASEB J. 2005, 19, 1492-1494. [CrossRef] [PubMed]

104. Bikov, A.; Gajdocsi, R. Exercise increases exhaled breath condensate cysteinyl leukotriene concentration in asthmatic patients. J. Asthma 2010, 47, 1057-1062. [CrossRef] [PubMed]

105. Arm, J.P.; Horton, C.E. Enhanced generation of leukotriene B4 by neutrophils stimulated by unopsonized zymosan and by calcium ionophore after exercise-induced asthma. Am. Rev. Respir. Dis. 1988, 138, 47-53. [CrossRef] [PubMed]

106. Li, K.L.; Lee, A.Y. Aspirin Exacerbated Respiratory Disease: Epidemiology, Pathophysiology, and Management. Med. Sci. 2019, 7, 45. [CrossRef] [PubMed]

107. Rajan, J.P.; Wineinger, N.E. Prevalence of aspirin-exacerbated respiratory disease among asthmatic patients: A meta-analysis of the literature. J. Allergy Clin. Immunol. 2015, 135, 676-681.e1. [CrossRef] [PubMed]

108. Sakalar, E.G.; Muluk, N.B. Aspirin-exacerbated respiratory disease and current treatment modalities. Eur. Arch. Otorhinolaryngol. 2017, 274, 1291-1300. [CrossRef]

109. Kim, S.D.; Cho, K.S. Samter's Triad: State of the Art. Clin. Exp. Otorhinolaryngol. 2018, 11, 71-80. [CrossRef]

110. Morales, D.R.; Lipworth, B.J. Safety risks for patients with aspirin-exacerbated respiratory disease after acute exposure to selective nonsteroidal anti-inflammatory drugs and COX-2 inhibitors: Meta-analysis of controlled clinical trials. J. Allergy Clin. Immunol. 2014, 134, 40-45. [CrossRef]

111. Steinke, J.W.; Borish, L. Factors driving the aspirin exacerbated respiratory disease phenotype. Am. J. Rhinol. Allergy 2015, 29, 35-40. [CrossRef]

112. Peters-Golden, M.; Gleason, M.M. Cysteinyl leukotrienes: Multi-functional mediators in allergic rhinitis. Clin. Exp. Allergy 2006, 36, 689-703. [CrossRef] [PubMed]

113. Milanovic, M.; Terszowski, G. IFN consensus sequence binding protein (Icsbp) is critical for eosinophil development. J. Immunol. 2008, 181, 5045-5053. [CrossRef] [PubMed]

114. Steinke, J.W.; Liu, L. Prominent role of IFN-gamma in patients with aspirin-exacerbated respiratory disease. J. Allergy Clin. Immunol. 2013, 132, 856-865.e3. [CrossRef] [PubMed]

115. Liu, T.; Kanaoka, Y. Aspirin-Exacerbated Respiratory Disease Involves a Cysteinyl Leukotriene-Driven IL-33-Mediated Mast Cell Activation Pathway. J. Immunol. 2015, 195, 3537-3545. [CrossRef] [PubMed]

116. Laidlaw, T.M.; Kidder, M.S. Cysteinyl leukotriene overproduction in aspirin-exacerbated respiratory disease is driven by platelet-adherent leukocytes. Blood 2012, 119, 3790-3798. [CrossRef] [PubMed]

117. Narayanankutty, A.; Resendiz-Hernandez, J.M. Biochemical pathogenesis of aspirin exacerbated respiratory disease (AERD). Clin. BioChem. 2013, 46, 566-578. [CrossRef]

118. Laidlaw, T.M.; Boyce, J.A. Pathogenesis of aspirin-exacerbated respiratory disease and reactions. Immunol. Allergy Clin. N. Am. 2013, 33, 195-210. [CrossRef]

119. Liu, T.; Barrett, N.A. Type 2 Cysteinyl Leukotriene Receptors Drive IL-33-Dependent Type 2 Immunopathology and Aspirin Sensitivity. J. Immunol. 2018, 200, 915-927. [CrossRef]

120. Cingi, C.; Muluk, N.B. Antileukotrienes in upper airway inflammatory diseases. Curr. Allergy Asthma Rep. 2015, 15, 64. [CrossRef]

121. Hoyte, F.C.L.; Nelson, H.S. Recent advances in allergic rhinitis. F1000Research 2018, 7. [CrossRef]

122. Figueroa, D.J.; Borish, L. Expression of cysteinyl leukotriene synthetic and signalling proteins in inflammatory cells in active seasonal allergic rhinitis. Clin. Exp. Allergy 2003, 33, 1380-1388. [CrossRef] [PubMed]

123. Shirasaki, H.; Kanaizumi, E. Expression and localization of the cysteinyl leukotriene 1 receptor in human nasal mucosa. Clin. Exp. Allergy 2002, 32, 1007-1012. [CrossRef] [PubMed] 
124. Suojalehto, H.; Kinaret, P. Level of Fatty Acid Binding Protein 5 (FABP5) Is Increased in Sputum of Allergic Asthmatics and Links to Airway Remodeling and Inflammation. PLoS ONE 2015, 10, e0127003. [CrossRef] [PubMed]

125. Xu, Y.; Zhang, J. The efficacy and safety of selective H1-antihistamine versus leukotriene receptor antagonist for seasonal allergic rhinitis: A meta-analysis. PLoS ONE 2014, 9, e112815. [CrossRef] [PubMed]

126. Liu, G.; Zhou, X. Oral Antihistamines Alone vs in Combination with Leukotriene Receptor Antagonists for Allergic Rhinitis: A Meta-analysis. Otolaryngol. Head Neck Surg. 2018, 158, 450-458. [CrossRef] [PubMed]

127. Seresirikachorn, K.; Chitsuthipakorn, W. Leukotriene Receptor Antagonist Addition to H1-Antihistamine Is Effective for Treating Allergic Rhinitis: A Systematic Review and Meta-analysis. Am. J. Rhinol. Allergy 2019. [CrossRef]

128. Cap, P.; Maly, M. Exhaled leukotrienes and bronchial responsiveness to methacholine in patients with seasonal allergic rhinitis. Ann. Allergy Asthma Immunol. 2009, 102, 103-109. [CrossRef]

129. Weidinger, S.; Novak, N. Atopic dermatitis. Lancet 2016, 387, 1109-1122. [CrossRef]

130. Vakharia, P.P.; Silverberg, J.I. New and emerging therapies for paediatric atopic dermatitis. Lancet Child. Adolesc. Health 2019, 3, 343-353. [CrossRef]

131. Nygaard, U.; Vestergaard, C. Emerging Treatment Options in Atopic Dermatitis: Systemic Therapies. Dermatology 2017, 233, 344-357. [CrossRef]

132. Jin, H.; He, R. Animal models of atopic dermatitis. J. Investig. Dermatol. 2009, 129, 31-40. [CrossRef] [PubMed]

133. Fogh, K.; Herlin, T. Eicosanoids in skin of patients with atopic dermatitis: Prostaglandin E2 and leukotriene B4 are present in biologically active concentrations. J. Allergy Clin. Immunol. 1989, 83, 450-455. [CrossRef]

134. Huang, Y.; Chen, G. Serum metabolomics study and eicosanoid analysis of childhood atopic dermatitis based on liquid chromatography-mass spectrometry. J. Proteome Res. 2014, 13, 5715-5723. [CrossRef] [PubMed]

135. Yoshida, S.; Yasutomo, K. Treatment with DHA/EPA ameliorates atopic dermatitis-like skin disease by blocking LTB4 production. J. Med. Investig. 2016, 63, 187-191. [CrossRef] [PubMed]

136. Sadik, C.D.; Sezin, T. Leukotrienes orchestrating allergic skin inflammation. Exp. Dermatol. 2013, $22,705-709$. [CrossRef] [PubMed]

137. Oyoshi, M.K.; He, R. Leukotriene B4-driven neutrophil recruitment to the skin is essential for allergic skin inflammation. Immunity 2012, 37, 747-758. [CrossRef] [PubMed]

138. Oyoshi, M.K.; He, R. Eosinophil-derived leukotriene C4 signals via type 2 cysteinyl leukotriene receptor to promote skin fibrosis in a mouse model of atopic dermatitis. Proc. Natl. Acad. Sci. USA 2012, 109, 4992-4997. [CrossRef]

139. Jeon, Y.H.; Min, T.K. A Double-Blind, Randomized, Crossover Study to Compare the Effectiveness of Montelukast on Atopic Dermatitis in Korean Children. Allergy Asthma Immunol. Res. 2016, 8, 305-311. [CrossRef]

140. Lee, A.Y. Is Montelukast Benefical in Children With Atopic Dermatitis? Allergy Asthma Immunol. Res. 2016, 8 , 279-281. [CrossRef]

141. Roekevisch, E.; Spuls, P.I. Efficacy and safety of systemic treatments for moderate-to-severe atopic dermatitis: A systematic review. J. Allergy Clin. Immunol. 2014, 133, 429-438. [CrossRef]

142. Crow, D.W.; Marsella, R. Double-blinded, placebo-controlled, cross-over pilot study on the efficacy of zileuton for canine atopic dermatitis. Vet. Dermatol. 2001, 12, 189-195. [CrossRef] [PubMed]

143. Woodmansee, D.P.; Simon, R.A. A pilot study examining the role of zileuton in atopic dermatitis. Ann. Allergy Asthma Immunol. 1999, 83, 548-552. [CrossRef]

144. Kupczyk, M.; Kuna, P. Targeting the PGD2/CRTH2/DP1 Signaling Pathway in Asthma and Allergic Disease: Current Status and Future Perspectives. Drugs 2017, 77, 1281-1294. [CrossRef] [PubMed]

145. Hewson, C.A.; Patel, S. Preclinical evaluation of an inhibitor of cytosolic phospholipase A2alpha for the treatment of asthma. J. Pharmacol. Exp. Ther. 2012, 340, 656-665. [CrossRef] [PubMed]

146. Yanes, D.A.; Mosser-Goldfarb, J.L. Emerging therapies for atopic dermatitis: The prostaglandin/leukotriene pathway. J. Am. Acad. Dermatol. 2018, 78, S71-S75. [CrossRef]

147. Bielory, L.; Schoenberg, D. Emerging Therapeutics for Ocular Surface Disease. Curr. Allergy Asthma Rep. 2019, 19, 16. [CrossRef]

148. Spada, C.S.; Woodward, D.F. Leukotrienes cause eosinophil emigration into conjunctival tissue. Prostaglandins 1986, 31, 795-809. [CrossRef] 
149. Andoh, T.; Sakai, K. Involvement of leukotriene B4 in itching in a mouse model of ocular allergy. Exp. Eye Res. 2012, 98, 97-103. [CrossRef]

150. Pelikan, Z. Mediator profiles in tears during the conjunctival response induced by allergic reaction in the nasal mucosa. Mol. Vis. 2013, 19, 1453-1470.

151. Dartt, D.A.; Hodges, R.R. Conjunctival goblet cell secretion stimulated by leukotrienes is reduced by resolvins D1 and E1 to promote resolution of inflammation. J. Immunol. 2011, 186, 4455-4466. [CrossRef]

152. Lambiase, A.; Bonini, S. Montelukast, a leukotriene receptor antagonist, in vernal keratoconjunctivitis associated with asthma. Arch. Ophthalmol. 2003, 121, 615-620. [CrossRef] [PubMed]

153. Simons, F.E.; Frew, A.J. Risk assessment in anaphylaxis: Current and future approaches. J. Allergy Clin. Immunol. 2007, 120, S2-S24. [CrossRef] [PubMed]

154. Butterfield, J.H. Increased leukotriene E4 excretion in systemic mastocytosis. Prostaglandins Other Lipid Mediat. 2010, 92, 73-76. [CrossRef] [PubMed]

155. Maekawa, A.; Austen, K.F. Targeted gene disruption reveals the role of cysteinyl leukotriene 1 receptor in the enhanced vascular permeability of mice undergoing acute inflammatory responses. J. Biol. Chem. 2002, 277, 20820-20824. [CrossRef] [PubMed]

156. Castells, M.; Butterfield, J. Mast Cell Activation Syndrome and Mastocytosis: Initial Treatment Options and Long-Term Management. J. Allergy Clin. Immunol. Pract. 2019, 7, 1097-1106. [CrossRef] [PubMed]

157. Valent, P.; Akin, C. Mast cell activation syndrome: Importance of consensus criteria and call for research. J. Allergy Clin. Immunol. 2018, 142, 1008-1010. [CrossRef] [PubMed]

158. Afrin, L.B.; Self, S. Characterization of Mast Cell Activation Syndrome. Am. J. Med. Sci. 2017, 353, $207-215$. [CrossRef] [PubMed]

159. Castells, M.; Austen, K.F. Mastocytosis: Mediator-related signs and symptoms. Int. Arch. Allergy Immunol. 2002, 127, 147-152. [CrossRef]

160. Sala, A.; Folco, G. Transcellular biosynthesis of eicosanoids. Pharmacol. Rep. 2010, 62, 503-510. [CrossRef]

161. Denzlinger, C.; Haberl, C. Cysteinyl leukotriene production in anaphylactic reactions. Int. Arch. Allergy Immunol. 1995, 108, 158-164. [CrossRef]

162. Tagari, P.; Rasmussen, J.B. Comparison of urinary leukotriene E4 and 16-carboxytetranordihydro leukotriene E4 excretion in allergic asthmatics after inhaled antigen. Eicosanoids 1990, 3, 75-80. [PubMed]

163. Kumlin, M.; Dahlen, B. Urinary excretion of leukotriene $\mathrm{E} 4$ and 11-dehydro-thromboxane B2 in response to bronchial provocations with allergen, aspirin, leukotriene D4, and histamine in asthmatics. Am. Rev. Respir. Dis. 1992, 146, 96-103. [CrossRef] [PubMed]

164. Armstrong, M.; Liu, A.H. Leukotriene-E4 in human urine: Comparison of on-line purification and liquid chromatography-tandem mass spectrometry to affinity purification followed by enzyme immunoassay. J. Chromatogr. B Analyt. Technol. Biomed. Life Sci. 2009, 877, 3169-3174. [CrossRef] [PubMed]

165. Lueke, A.J.; Meeusen, J.W. Analytical and clinical validation of an LC-MS/MS method for urine leukotriene E4: A marker of systemic mastocytosis. Clin. BioChem. 2016, 49, 979-982. [CrossRef] [PubMed]

166. Hagan, J.B.; Laidlaw, T.M. Urinary Leukotriene E4 to Determine Aspirin Intolerance in Asthma: A Systematic Review and Meta-Analysis. J. Allergy Clin. Immunol. Pract. 2017, 5, 990-997.e1. [CrossRef] [PubMed]

167. Rabinovitch, N.; Silveira, L. The response of children with asthma to ambient particulate is modified by tobacco smoke exposure. Am. J. Respir. Crit. Care Med. 2011, 184, 1350-1357. [CrossRef] [PubMed]

168. Vachier, I.; Kumlin, M. High levels of urinary leukotriene E4 excretion in steroid treated patients with severe asthma. Respir. Med. 2003, 97, 1225-1229. [CrossRef]

169. Divekar, R.; Hagan, J. Diagnostic Utility of Urinary LTE4 in Asthma, Allergic Rhinitis, Chronic Rhinosinusitis, Nasal Polyps, and Aspirin Sensitivity. J. Allergy Clin. Immunol. Pract. 2016, 4, 665-670. [CrossRef]

170. Marmarinos, A.; Saxoni-Papageorgiou, P. Urinary leukotriene E4 levels in atopic and non-atopic preschool children with recurrent episodic (viral) wheezing: A potential marker? J. Asthma 2015, 52, 554-559. [CrossRef]

171. Chiu, C.Y.; Tsai, M.H. Urinary LTE4 levels as a diagnostic marker for IgE-mediated asthma in preschool children: A birth cohort study. PLoS ONE 2014, 9, e115216. [CrossRef]

172. Kaditis, A.G.; Alexopoulos, E. Urine concentrations of cysteinyl leukotrienes in children with obstructive sleep-disordered breathing. Chest 2009, 135, 1496-1501. [CrossRef] [PubMed]

173. Satdhabudha, A.; Sritipsukho, P. Urine cysteinyl leukotriene levels in children with sleep disordered breathing before and after adenotonsillectomy. Int. J. Pediatr. Otorhinolaryngol. 2017, 94, 112-116. [CrossRef] [PubMed] 
174. Rabinovitch, N.; Graber, N.J. Urinary leukotriene E4/exhaled nitric oxide ratio and montelukast response in childhood asthma. J. Allergy Clin. Immunol. 2010, 126, 545-551.e4. [CrossRef] [PubMed]

175. Rabinovitch, N.; Mauger, D.T. Predictors of asthma control and lung function responsiveness to step 3 therapy in children with uncontrolled asthma. J. Allergy Clin. Immunol. 2014, 133, 350-356. [CrossRef] [PubMed]

176. Sunkonkit, K.; Sritippayawan, S. Urinary cysteinyl leukotriene E4 level and therapeutic response to montelukast in children with mild obstructive sleep apnea. Asian Pac. J. Allergy Immunol. 2017, 35, $233-238$. [CrossRef] [PubMed]

177. Kwon, S.Y.; Ro, M. Mediatory roles of leukotriene B4 receptors in LPS-induced endotoxic shock. Sci. Rep. 2019, 9, 5936. [CrossRef] [PubMed]

178. Zheng, L.X.; Li, K.X. Pain and bone damage in rheumatoid arthritis: Role of leukotriene B4. Clin. Exp. Rheumatol. 2019, in press.

179. Zhou, J.; Lai, W. BLT1 in dendritic cells promotes Th1/Th17 differentiation and its deficiency ameliorates TNBS-induced colitis. Cell Mol. Immunol. 2018, 15, 1047-1056. [CrossRef]

180. Madeira, M.F.M.; Queiroz-Junior, C.M. The role of 5-lipoxygenase in Aggregatibacter actinomycetemcomitans-induced alveolar bone loss. J. Clin. Periodontol. 2017, 44, 793-802. [CrossRef]

181. Hikiji, H.; Ishii, S. A distinctive role of the leukotriene B4 receptor BLT1 in osteoclastic activity during bone loss. Proc. Natl. Acad. Sci. USA 2009, 106, 21294-21299. [CrossRef]

182. Sezin, T.; Krajewski, M. The Leukotriene B4 and its Receptor BLT1 Act as Critical Drivers of Neutrophil Recruitment in Murine Bullous Pemphigoid-Like Epidermolysis Bullosa Acquisita. J. Investig. Dermatol. 2017, 137, 1104-1113. [CrossRef] [PubMed]

183. Toda, A.; Terawaki, K. Attenuated Th1 induction by dendritic cells from mice deficient in the leukotriene B4 receptor 1. Biochimie 2010, 92, 682-691. [CrossRef] [PubMed]

184. Lv, J.; Zou, L. Leukotriene B(4)-leukotriene B(4) receptor axis promotes oxazolone-induced contact dermatitis by directing skin homing of neutrophils and CD8(+) T cells. Immunology 2015, 146, 50-58. [CrossRef] [PubMed]

185. Sumida, H.; Yanagida, K. Interplay between CXCR2 and BLT1 facilitates neutrophil infiltration and resultant keratinocyte activation in a murine model of imiquimod-induced psoriasis. J. Immunol. 2014, 192, 4361-4369. [CrossRef] [PubMed]

186. Hegde, B.; Bodduluri, S.R. Inflammasome-Independent Leukotriene B4 Production Drives Crystalline Silica-Induced Sterile Inflammation. J. Immunol. 2018, 200, 3556-3567. [CrossRef] [PubMed]

187. Sasaki, F.; Koga, T. Leukotriene B4 promotes neovascularization and macrophage recruitment in murine wet-type AMD models. JCI Insight 2018, 3. [CrossRef] [PubMed] 